\title{
THEORETICAL ISSUES IN HUMAN RESOURCES MANAGEMENT: FROM TAYLORISM TO THEORY Z
}

\author{
Badom Monbari Porbari (PhD) ${ }^{1}$ and Girigiri Barinem Wisdom (Ph.D) ${ }^{2}$ \\ ${ }^{1}$ Department of Sociology, Faculty of Social Sciences, University of Port Harcourt, Nigeria \\ ${ }^{2}$ Department of Sociology, Faculty of Social Sciences, Rivers State University, Nigeia
}

Cite this article:

Badom M.P., Girigiri B.W. (2021), Theoretical Issues in Human Resources

Management: From Taylorism to Theory Z. British Journal of Management and Marketing Studies 4(3), 1-20. DOI: 10.52589/BJMMSBO8QJCHP.

\section{Manuscript History \\ Received: 8 June 2021 \\ Accepted: 5 July 2021 \\ Published: 19 July 2021}

Copyright $\odot 2020$ The Author(s). This is an Open Access article distributed under the terms of Creative Commons AttributionNonCommercial-NoDerivatives 4.0 International (CC BY-NC-ND 4.0 ), which permits anyone to share, use, reproduce and redistribute in any medium, provided the original author and source are credited.
ABSTRACT: The human resources of any given organisation are the greatest assets that should be managed in order to attain desired performance goals. Thus, human resources management is the bedrock of all management activities in any formal work setting. In the bid to achieve organizational goals, there is need to manage the human resources with established knowledge which scientifically related methods yield. This is termed human resources management theory which is a system of interconnected propositions that condenses and organizes the knowledge about the social world, nay work organizations and explains the workings of the work organizations. Secondary data were garnered to elicit information for the analysis of the paper which presents relevant theories of industrial organizations and critically analysed them so as to acquaint us with the knowledge and effectiveness of the theories. This is essentially a metatheoretical schema for theories adopted in the motivation of human resources in order to attain deeper understanding of theories of human resources management.

KEYWORDS: Theory, Motivation, Human Resources, Performance 


\section{INTRODUCTION}

Theory is a very important concept and adopted in various disciplines in a bid to establish fact from objectivity. A theory is a logically set of coherent, interrelated propositions that attempts to make sense of observable phenomena and predict behaviour or attitudes that will likely occur under specified condition(s). In the field of industrial relations and human resources management, facts do not speak for themselves. For it to be done in a scientific way there must be a set of logical ideas that make provision for better understanding of organisations. Human resources managers do not have to manage the human resources with mere guesses as it was earlier done with the rule of thumb method. The present era of science fewer ways for theory formulation to conform with the scientific standard. In such manner different persons can adopt a particular method. Theory thus becomes a window through which the social scientist sees the society. Managers have long theorized about the workings of work organisations and the facts that necessitated organizational efficiency.

In the world of work, several theories have been advanced to help in the management of the human resource. Starting with Frederick Taylor who in 1886 presented a paper at a national meeting of engineers entitled "The engineer as an Economist". This paper including others prepared by Taylor expressed his philosophy of scientific management (Gabor, 2000). "Scientific management is the name ascribed to a philosophy and set of methods techniques that stressed the scientific study and organisation of work at the operational level for the purpose of increasing efficiency" Aswathappa (2002:317).

Taylor's concept of scientific management dominated thought about management from 1900 to 1930. Subsequently, the scientific management principles were rebelled against by trade unions. The reason is that Taylor's failed to address the needs of employees as it relates to their motivation to work. Then Human relations school came up with new theories. These were the early theories. As society evolved, theorists in the contemporary period develops a somewhat different theories owing to their dissatisfaction with earlier theories. We shall therefore study each of these theorists to under stand the plethora of approaches to the management and motivation of the human resources of varied organisations. 


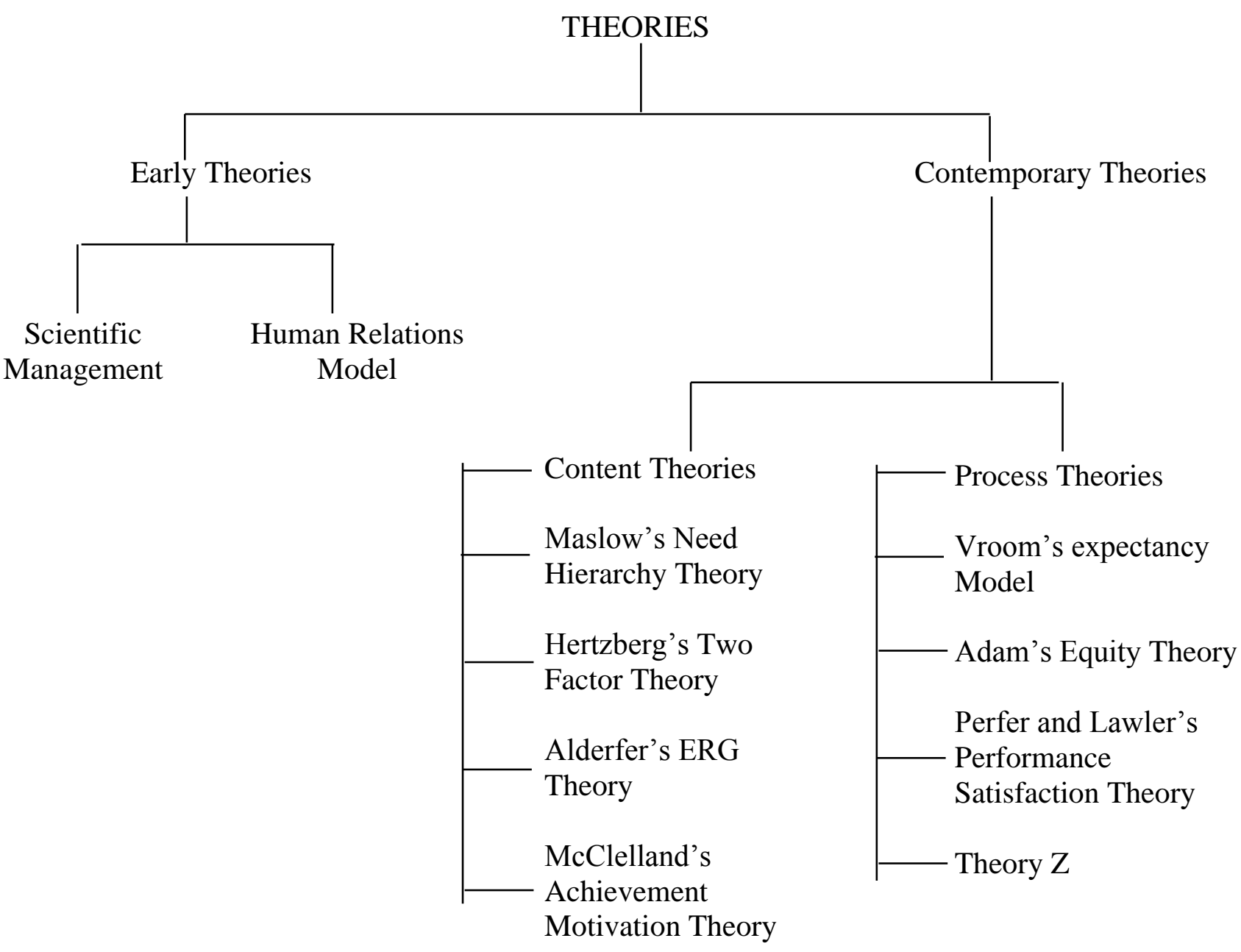

\section{EARLY THEORIES}

\section{Taylor's Scientific Management}

Frederick W. Taylor is the major proponent of the body of literature that emerged during the period 1890 - 1930. his philosophical ideas was titled scientific management, which major objective was "to remove the causes for antagonism between the boss and the men who were under him" (Taylor, 1947:128). By this Taylor identified the role of other innovations in management and work organisations, namely, inspection systems and employment departments (Urwick and Brech, 1949:33). He believed that if employees and workers together concentrated on method to increase production (through better costing procedures, premium and incentive payments, time and motion studies), if they would only take "their eyes off the division of the surplus as the all important matter and together turn their attention toward increasing the size of the surplus, then there would be efficiency and surplus for all so that there would not be conflict (Mamoria and Gankar, 2009:545; Taylor, 1947:129). Taylor's philosophy was also referred to as Taylorism. Taylorism was thus geared towards 
the systematization of management and the regulation and control of production in work organisation.

The following four principles according to Ivancevich, Konopaske and Matteson (2005:9) constituted Taylor's concept of scientific management. Specifically in their opinion Taylor's principles of management were tied to:

1. Develop a science for each element of an employee's work, which replaces the old rule-of-thumb method.

2. Scientifically select and then train, teach, and develop the worker, whereas in the past a worker close the work to do and was self-trained.

3. Heartily corporate with each other to ensure that all work was done in accordance with the principles of science and

4. Provide an almost equal division of the work and the responsibility between employers and employees.

The major point in Taylor's principles was that maximum benefit for society emanates from a sound labour relation between management and employees.

Similarly, to the above principles, Aswathapa (2002:317) opined that scientific management had contributed several techniques which are still relevant. The techniques include;

1. Scientific method of doing work

2. Planning the task

3. Scientific selection; training and remuneration of workers

4. Standardization

5. Specialization and division of work

6. Time and motion studies

7. Mental revolution

Taylor's theory emphasized individual and group needs. At the individual level, employees are expected to be motivated if they are economically rewarded and ill obey directives if their economic conditions are so improved. Taylor adjusted his theory as the surest means of enhancing organizational effectiveness, and for some years, his scientific management received recognition and this led to the development of separated discipline called "Human Engineering", which is the study of people at work and of work methods; it entails a study of equipment design, facing of work, hours of work and conditions of work bordering on the environment (Harrel, 1972).

Inspite of the promises of Taylor's scientific management, as with most theories, it was not without criticisms. In the first place, Taylor's emphasis on output and efficiency failed to address the needs of employees. This trade union fought against Taylor's attention on scientific management principles (Ivancevich, Konofaske and Matteson, 2005:12). 
Second, behavioural scientists in the words of Aswathapa (2002:318) ' have argued that Taylor and his colleagues dehumanized workers by treating them as mere factors of production, who could be manipulated completely through economic incentives". In similar way, Mamoria and Gankar (2009:546) stressed that Taylor's approach take workers as mere "economic tools", separate as mechanical parts of production process, and not as "human beings".

Third, it is called a "rabble hypothesis" which consigns society to a group of unorganized individuals who believe the same way and are moved by the same thing and therefore use one's behaviour for another. In other words, it is over simplistic to assume that the interest of the worker is economic gain, in the form of higher wages. The worker may have other needs.

Finally, Cole (2004:2) added the following. The drawbacks to scientific management were principally the following;

- It reduced the worker's role to that of a rigid adherence to methods and procedures over which he had no discretion.

- It led to the fragmentation of work on account of its emphasis on the analysis and organisation of individual tasks or operations.

- It generated a "carrot-and-stick" approach to the motivation of employees by enabling pay to be geared tightly to output.

- It put the planning and control of workplace activities exclusively in the hands of the management.

- It ruled out any realistic bargaining about wage rates since every job was measured, tied and rated 'scientifically'.

\section{Human Relations Theory}

Owing to the inadequacy of the assumption that workers primary motivation was economic in addition to other related criticisms, a group of Havard University researchers were asked to study work groups activities at Western Electric's Hawthorne plant outside of Chicago (Cicero, Illinois) Mayo (1945) in Ivancevich, Kenepaske and Matteson (2005:12).

These researches had Elton Mayo, Fritz Roethlisberger, and William Dickson as leaders of the study team. This research as conducted with a longitudinal design. The Hawthorne studies was conducted in five stages (Cole, 2004:33). First stage was from $1924-1927$. This stage was concerned with the effects of lighting on output. The second stage which became known as the relay assembly test room started from $1927-1929$. Their third stage was from 1928 - 1930. Forth stage (1932) and the final stage took place in 1936.

The Hawthorne studies conclusively through quantitative measurements that "social contacts which the workers had at workplaces were also important and that the boredom and repetitiveness of tasks were themselves factors in reducing motivation. Mayo and others also believe that managers could motivate employees by acknowledging their social needs and by making them feel useful and important" (Aswathapa, 2002:318). 
They stressed the importance for the understanding of the needs and social aspect of employees' life. This model craves that interpersonal relationship should be fostered in the work place hence it is referred to as human relations school.

Cole (2004:34) gave the following as conclusion's drawn from the Hawthorne experiments. They are;

1. Individual workers cannot be treated in isolation, but must be seen as members of a group.

2. They need to belong to a group and have status within it. This is more important than monetary incentives or good physical working conditions.

3. Informal groups at work exercise a strong influence over the behaviour of workers.

4. Supervisors and managers need to be aware of these needs and cater for them if workers are to collaborate with the official organisation rather than work against it.

Owing to the findings, employees were given the liberty to make their decisions on their jobs. By this, workers can be allowed to relate with every category of staff. Inspite of the findings and application of these theories in the motivation of workers, it is not devoid of criticisms. Behavioural scientists claim that it lacks scientific objectivity in among at conclusions. It has also been criticized for given greater attention to social contacts at workplace as a way of motivating workers.

Landsberger (1958) in Mamoria and Gankar (2009:547) argued that criticisms of the Hawthorne studies are that:

1. The Hawthorne researchers did not give sufficient attention to the attitudes that people bring with them to the work place. They did not recognize such forces as class consciousness, the role of unions and other extra - plant forces on attitudes of workers.

2. The Hawthorne plant was not a typical plant because it was a thoroughly unpleasant place in which to work.

3. The Hawthorne studies look upon the worker as "a means to an end", not as "an end in himself". They assume acceptance of management's goals and look on the worker as someone to be stimulated by management.

\section{CONTEMPORARY THEORIES}

\section{Content Theories of Motivation}

There are some theories of motivation which are characterized as content theories. They are so referred based on the belief that the content of motivation entails needs within the person. "The content theory of motivation is based on the factors within the person that energize, direct, sustain and stop behaviour." The content theories focus on needs that motivate people. It is pertinent to stress that all persons may not be motivated by the same need all the time. It is not every need that equally important for an individual at any one time. "To restore the 
balance, a goal that will satisfy the need is identified, and a behaviour pathway that will lead to the achievement of the goal is selected. Therefore, all behaviour is motivated by unsatisfied needs (Armstrong, 2006:255). To make it more explicit, content theories reveal that the managerial role is to create work circumstances that respond positively to the needs of the employees. Four important content theories have been identified. They are

1) Maslow's need hierarchy theory

2) Alderfer's ERG theory

3) Hertzberg's two-factor theory and

4) McClelland's

\section{Maslow's Need Hierarchy Theory}

The need hierarchy theory was propounded by Abraham Harold Maslow who posits that needs are arranged in a hierarchy (Maslow and Kaplan, 1998). Maslow's theory holds that human beings have needs that can influence their behaviour. He classified needs into lowest level needs which entail the physiological needs and the highest-level needs which are the self actualization needs. The difference between them is that the lower-level needs are predominantly satisfied (Ivancevich, Konopaske and Matteson (2005:141) externally while the high-level needs are internal to the person (Mameria and Gankar, 2009:568). These needs according to Maslow must be unsatisfied needs in order to influence behaviour, this is because a satisfied need no longer motivate behaviour.

The theory stressed that these needs are arranged in order of importance, or hierarchy. These needs are arranged in five categories starting with the basic (physiological) to the complex (self actualization). That on individual advances from the basic level of need to the next level, up to the last level of need.

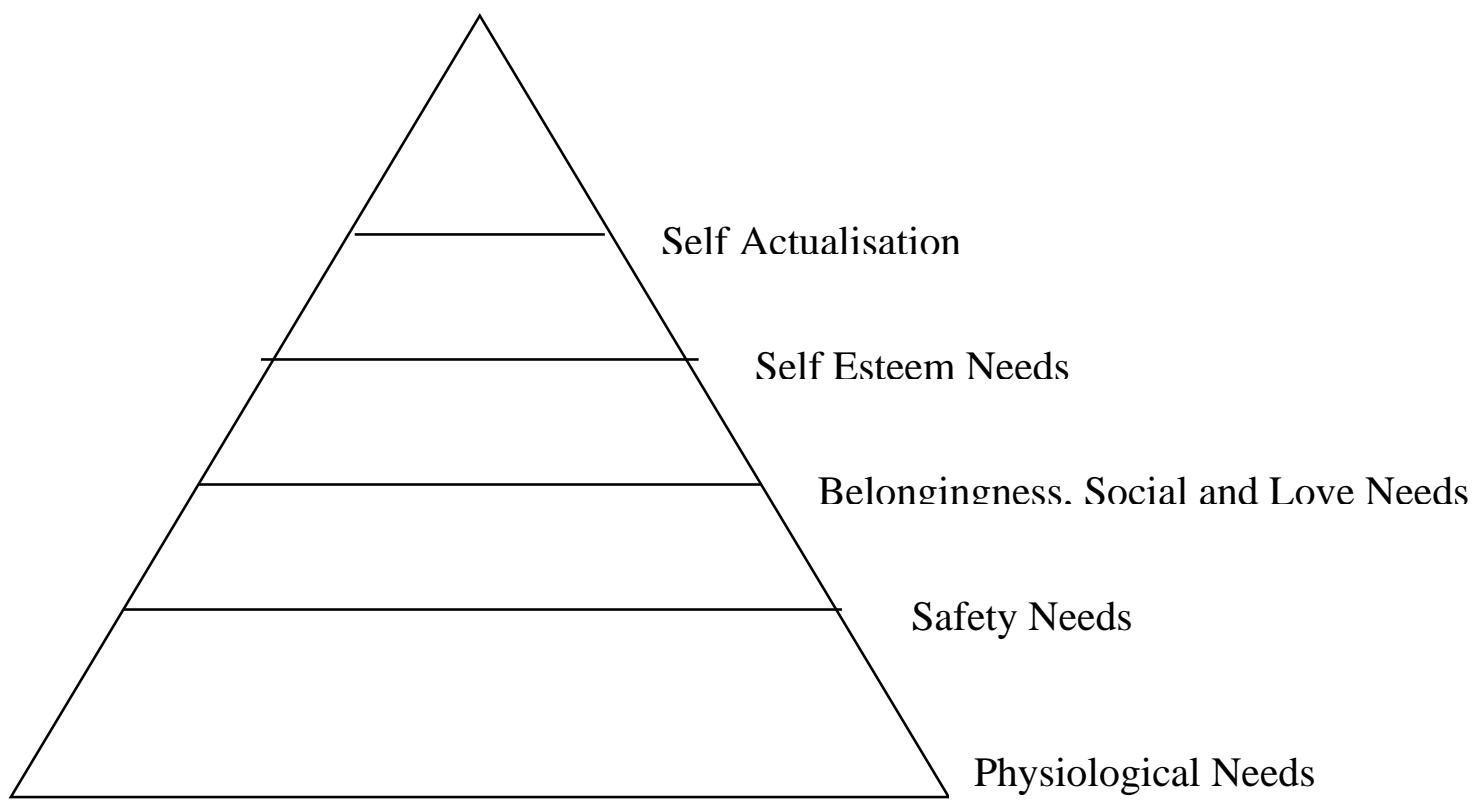

Fig. 5.2 
Physiological Needs: This is the lowest level needs and the basic needed for the survival of an individual. These basic needs re given in teralia: food, drink (water), shelter, sex, relief from pain, clothing. These physiological needs are biological needs of the body. The individual worker strive to acquire these low level needs before he thinks of high level needs, and when the first level needs are acquired, they no longer drive an individual worker's behaviour. It is at this point he aspires for a high-level need. Evidently, our nation is in the grip of recession and unemployment and poverty is rampant. This will therefore make the physiological needs a drive to many people. A hungry person will not aspire for spending his holiday in another planet. His major need is driven around food. In the light of this, Maslow (1970:37) stressed inter alia:

"For our chronically and extremely hungry man, utopia can be defined simply as a place where there is plenty of food. He tends to think that, if only he is guaranteed, food for the rest of his life, he will be perfectly happy and will never want anything more. Life itself tends to be defined in terms of eating. Anything else will be defined as unimportant. Freedom, love, community feeling, respect, philosophy, may all be waved aside as fripperies that are useless, since they fail to fill the stomach. Such a man may fairly be said to live by bread alone".

It is the prerogative of management to avail employees the opportunity to acquire this need through the payment of fair and adequate salary and waged and the provision of other incentives.

Safety Needs: This refers to an individual's need for freedom from threat. In other words, it entails the need for protection from dangerous situations. In Maslow's theory, this is the next need after the physiological needs. It is fundamental that a worker who has attained the physiological need is in need of security in the present-day Nigeria. An average worker of the middle class tends to face the danger of kidnapping and theft; therefore, it is his priority to protect his physiological needs achieved. Even if Maslow suggested that safety needs are mostly readily observed in infants and young children owing to their helplessness and dependence on adults, it exerts its influence beyond that class. Adult workers are in dire need to have their wages and salary secured. An adult worker who has acquired his physiological needs from the wages and salary paid him is also bound to protect his job by being a member of labour union through which workers bobby for legislations that secure workers' positions. In addition, managerial practices to satisfy the safety needs of employees include pension schemes, group insurance, provident fund, gratuity, safe working conditions, grievance procedure, system of seniority to govern lay-off and others (Aswathapa, 2002:321).

Belongingness, Social and Love Needs: The belongingness, social and love needs is the third category of the hierarchy of needs. They arise only when the first two categories of needs are satisfied. This is an individual's need for friendship, affiliation, interaction and love. "Non-satisfaction of this need may affect the mental health of the employee. Management can play a vital role in fulfilling this category of needs by permitting social interaction and membership groups particularly stable informal groups and encouraging cooperation among workers" (Peretomode and Peretomode, 2001:237). As stressed by Maslow, this category of need is tied to giving and receiving love. As such, workers need a friendly organization.

Self Esteem Needs: Self esteem needs is concerned with the need for self-esteem and for esteem from others. In other words, it refers to the need for self respect and feeling of self 
importance and recognition from people. As the fourth level of need, satisfaction of it generates self confidence and the thought of being important. Failure to achieve this need may generate inferiority and thus necessitate feeling of discouragement. Maslow stressed that the best form of self esteem is based on feeling of respect earned from others and not necessarily fame, status and self praises. In the work organizations, an individual employee should be eligible to take positions higher than to him owing to the mastery of jobs and the level of creativeness that he puts in tasks given him. Therefore, job title, supervisory recognition, responsibility, publicity in company publications and challenging tasks enhance self-esteem in the work organizations.

"One of the implications of Maslow's theory is that the higher-order needs for esteem and self fulfillment provide the greatest impetus to motivation - they grow in strength when they are satisfied, while the lower needs decline in strength on satisfaction" (Armstrong, 2006:258).

Self-Actualization Needs: This constitutes the final level needs that are sought after the satisfaction of the first four level needs. Self actualization needs refer to the need of an individual to fulfill oneself through maximum application of one's abilities, skills and potentialities. Maslow avers that it is "the desire to become everything one is capable of becoming", through one's capabilities to the realization of potentials.

Maslow's need hierarchy theory is appreciated for its usefulness in the management of the workers variety of needs. It is however, not without criticisms. Maslow's proposition that the needs are in ascending order, and that the physiological needs must be fulfilled for the 'higher order' needs is not supported (Thompson and Mchugh, 2002:295). Related to this position, Lawler and Suttle $(1972 ; 265-87)$ stressed that data from managers of two varies confirms provided little support about the existence of a hierarchy of needs. They rather found that only two levels of need exist. First, physiological need and second is a need level that comprise of all other needs.

Furthermore, "Maslow proposed that the typical adult in society has satisfied about 85 percent of the physiological need; 70 percent of the safety and security needs; 50 percent of the belongingness, social, and love needs; 40 percent of the esteem needs; and 10 percent of the self actualization need. Many critics disagree with these figures, however, particularly the 10 percent figure for self actualization", (Invancevich, Konopaske and Matteson, 2005:142). Also, the need hierarchy theory as a point of merit has apprised managers of different individual needs that should be satisfied in order to motivate employees and as a result of their familiarity with these needs will recognize that the needs may be different for each employee and therefore realise that giving of the same reward has the probability of owing a negative impact on motivation (Davis and Newsfrom, 1989:109).

\section{Two-Factor Theory}

Frederick Herzberg proposed another theory of motivation called the two-factor-theory which is variously named as the dual-factor theory, the motivation-hygiene theory, dissatisfierssatisfiers, and the extrinsic-intrinsic factors. This depends on the discussant of the theory.

Herzberg's theory is focused on satisfaction at work, and presents two separate conditions in the workplace. First, there is a set of extrinsic conditions in the job context which results in worker dissatisfaction if they are absent. These conditions even if they are present in the job 
context, do not necessarily motivate workers. Herzberg refers to this condition as "dissatisfiers" or "hygiene" factors, because their presence in the job context is to prevent a level of dissatisfaction. The conditions that lead to this level include;

1. Salary

2. job Security

3. Working conditions

4. Status

5. Company procedures

6. Quality of technical assistance

7. Quality of interpersonal relations among peers, with superiors, and with subordinates.

Furthermore, the next are referred to as intrinsic work conditions. Their presence in the job context enhances a high level of motivation that can cause an organisation to have a high level of job performance. For jobs to prove satisfying, they should be present, otherwise, jobs do not prove highly satisfying. The set of factors are known as satisfiers or motivators. They include:

1. Achievement

2. Recognition

3. Responsibility

4. Advancement

5. The work itself

6. The possibility of growth

"Herzberg's two-factor theory has important applications in human resources management. It suggests that to motivate employees, managers should focus on the motivators while at the same time try to maintain the hygiene factors at an appropriate level so as to prevent dissatisfaction (Peretomode and Peretomode, 2001:239). 


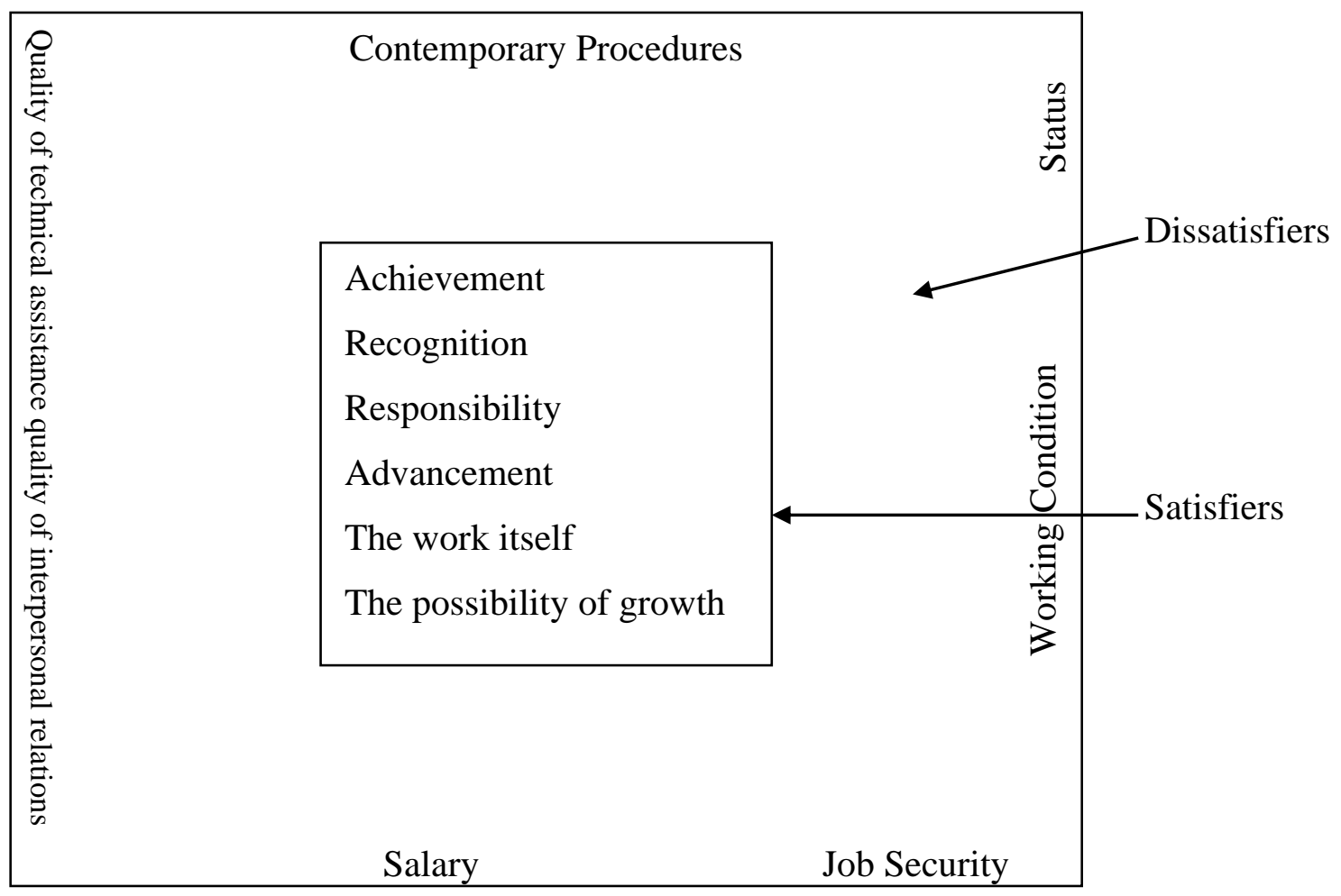

Fig. 5.3: Dissatisfiers and Satisfiers

Herzberg's two-factor theory is rooted in Maslow's needs theory of motivation. Maslow proposed a five level needs theory as opposed to Herzberg's two levels of needs - intrinsic and extrinsic. Similarly, proper analysis of this theory shows that Taylor and his colleagues were focused in the same direction with the two-factor theory, specifically in terms of incentives, pay, supervision and favourable working conditions.

Like other theories, two-factor theory has being landed. It stimulated a whole lot of thought and research on the issue of workers motivation. As opined by Aswathapa (2002:327), Herzberg's two factor theory contributed to the job-design technique of job enrichment. "Job enrichment is defined as the process of building personal achievement, recognition, challenge, responsibility, and growth opportunities into a person's job", (Ivancevich, Konopaske and Matteson, 2005:146). Also, the theory offers some action recommendations which aid managers in the motivation of employees. Herzberg's theory revealed that monetary reward was not to be viewed as a major force on the job. The theory was not without criticisms. First, Herzberg's methodology has being questioned. Second, the twofactors in the theory are not actually distinct. Both satisfiers and dissastisfiers contribute to satisfaction as well as dissatisfaction. Many other criticisms bound, but this does not limit its impact on practicing managers. 


\section{ERG Theory}

ERG theory was developed by Alderfer (Alderfer, 1972). The proponent of this theory is in agreement with Maslow that individual needs abound and that they are hierarchically arranged. However, alderfer's proposed need involve only three levels of needs which he believed determine the behaviour of humans in the workplace. In the theory, $\mathrm{E}$ - stands for Existence, ' $r$ ' stands for Relatedness and " $G$ " for growth. Therefore, in the context of this theory the three level of needs are;

1. Existence: this level of needs is satisfied by such factors as, food, drink (water) pay, and working conditions.

2. Relatedness: This entails needs such as having meaningful social ties and interrelationship.

3. Growth: This refers to needs satisfied by an individual's creative and productive contributions. Alderfer's ERG Theory have some similarity with Maslow's hierarchy of needs, when we equate Alderder's Existence needs to Maslow's physiological and safety needs; the relatedness needs are like the belongingness, social and love category of Maslow's and the growth needs are similar to the high other needs of esteem and self-actualisation in Maslow's theory. Just like Alderfer categorized his needs level into three, against Maslow's five hierarchies of needs, he suggests that the three levels of needs does not have a rigid hierarchy, in which a lower level of need must be satisfied before a higher level of needs. Alderfer proposes a flexible needs level, where a frustration - regression process is at work. By this, Alderfer means that if an individual is constantly frustrated in a bid to satisfy growth needs, relatedness needs resurfaces as a motivating need thereby causing the individual to redirect his actions towards satisfying a lower level need. This is contrary to Maslow's hierarchy of needs theory which states that an individual will stay at a particular level with (that need is satisfied).

Alderfer's theory is thus of great benefit to human resources manager, who in course of motivating worker can apply the frustration - regression dimension of the theory an employees who is frustrated at a higher level need.

ERG theory in evaluation its need explanations are popular inspite of few research verification. This is because of its simple and not difficult expressed views of human behaviour (Salancik and Pfeffer, 1977). Secondly, inspite of some available evidence to counter the theory's predictive value, most contemporary researches on motivation seems to support Alderfers theory against Maslow's and Herzberg's theories. Most importantly, ERG theory tends to uphold major points of the content theories and has less limits and restriction.

Thirdly, the ERG theory has shown mere consistency with our perceptions of human variations. It is therefore, a more reliable version of the need hierarchy (Robbins, 1989:55).

However, the merits, ERG theory has some criticisms. It is seen as a newer theory which has not stimulated a great deal of research like the need hierarchy theory (Aswathapa, 2002:328, Ivancevich, Konopaske and Matteson, 2005:144). 
Finally, the theory lacks definite guidelines. It only presents a model and implies that individuals are bound to be motivated to involve in behaviour which will satisfy any of those levels of need proposed in the theory (Feldman and Arnold, 1983:11).

\section{Achievement Motivation Theory}

Achievement motivation theory also called learned needs theory was proposed by David C., McClelland and his colleagues, who believes that a number of needs are derived from the culture (McClelland, 1962:100). According to this theory, there are three needs that motivate the behaviour of human being. These needs are the need for achievement (nAch), the need for affiliation (nAff), and the need for power (nPow). McClelland holds that different individuals have the need for all the three needs, but that people differ in the way in which the various needs motivate their behaviour. He avers that when a need is strong in an individual, it will cause him to be motivated to adopting behaviour that drives its satisfaction. These needs, Maslow believed are learned through adaptation with one's environment. Therefore, since needs are learned, behaviours which attract rewards seem to occur again at a greater level.

Need for Achievement (nAch): Individuals are known for setting goals and putting in efforts to achieve target goals and subsequently achieve set goals. This gives an individual a high satisfaction. Goal achievement is mostly attract financial reward which in most societies is indicative of one's level of achievement: McClelland theory shows a description of some factors which reveal a high need for achievement.

1) The individual is willing to take responsibility for solving problems.

2) The person seems to set moderate achievement goals and is willing to take risks to achieve them.

3) The person anticipates performance feed back.

Need For Power (nPow): Employees whose drives are geared towards giving power anticipates to exercise authority and influence decisions in the organization. Satisfaction is derived from holding higher positions of authority that will make one control subordinates. Employees of various work organizations anticipate higher organizational positions through promotion in order to satisfy these needs.

Need For Affiliation (nAff): The need for affiliation shows a desire to relate closely with others. An individual with the need for affiliation seek satisfaction in the context of social and interpersonal activities.

As usual with any other theory, McClelland's theory has received a lot of criticisms. In the first place, most of the available evidence in support of this theory, emanated from McClelland's and his supporters.

Secondly, the methodology adopted by the theorist is questioned as unscientific. McClelland used the thematic appreciation test (TAT) of Murray as the tool used for determining basic needs.

Thirdly, the theory is criticized on the contemporary by whether the needs are permanently acquired. Research is needed to show whether acquired needs lost over a period of time. 


\section{Process Theories}

The last pages dealt with content theories, which stress the importance of inner needs in motivation. The following theories are process theories which are concerned primarily with how an individuals behavior is energized, directed, maintained, and terminated. The category of theories has three which are termed process theories. There are three of these theories namely, expectancy theory, equity theory, and goal setting theory.

\section{Expectancy Theory}

Expectancy theory as other explanations of motivation was developed by Victor Vroom (vroom, 1964). Apart from expectancy theory, it also is referred to as instrumentality, theory, path-goal theory and valence-instrumentality-expectancy (VIE) theory. Having its roots in the cognitive concepts of pioneer psychologists, Kurt Lewin and Edward Tolman, and in the choice behavior and utility concepts of the classical economic theories, Vroom defined in formulating an expectancy theory directly focusing on work motivation, and is based on the perception that work efforts is geared towards behaviors which people believe will bring desired outcomes. In the work organizations, employees develop expectations bordering in the possibility of achieving different levels of job performance. Thus, humans direct efforts towards outcomes that assist in the fulfillment of their needs. Motivation in the opinion of Vroom is defined as a process, governing choices among alternative forms of voluntary activity. For proper understanding of the theory, it is pertinent to explain the four variables of the theory, and explain how they operate. The four variables are: First-Aid, second-level outcomes, instrumentality, valence, and expectancy.

\section{First-Level and Second-Level Outcomes}

First-level outcomes emanating from behavior refers to performance achieved as a result of doing the job itself and includes productivity, absenteeism, turnover, and quality of productivity. The second level outcomes are the rewards, either positive jor negative that the first level-outcomes are likely to produce. They include, merit pay increases, group acceptance or rejection, promotion and termination. They also include job security (Hellriegel, et al, 2001: 147).

Expectancy: This is the, perception of an individual that a particular level of effort will produce a particular outcome, and mostly the conceived of as a single-probability statement. That is, it means there is a behalf about the chance of something occurring as a result of the behavior. "From a managerial perspective, expectancy theory suggests that the manager should develop an awareness of employee thought processes and based on that awareness, take actions that will influence those processes in a manner that facilitates the attainment of positive organizations outcomes." (Ivancevich, Konopaske and Matheson, 2005:150). It is also expected of managers to implement fair, meaningful and easy to-understand performance review and evaluation systems. As opined in Dennelly Gibson and Ivancevich (1983:323) managers in the application of the expectancy theory need to be apprised of three important things. First, they should know the employees perception of looking hard and aspiration for achievement of a particular level of performance. Second, managers should verify if an employee's perception of whether the attainment of a certain level of performance emanate from various outcomes-either positive or negative. Third, managers should know the degree of value attributed to outcomes by employees. 
Instrumentality: This is the perception by an individual that first-level outcomes (performance) are associated with second-level outcomes (rewards). It refers to the individuals behalf that the attainment of certain outcomes will lead to the attainment of the second-level outcomes.

Valence: Valence refers to the individuals preference for a second-level outcomes. Valence can have both negative and positive values outcomes that have a negative value are not preferred and one avoided, while positive value outcomes are preferred.

\section{Evaluation of Expectancy Theory}

Expectancy theory, like other theories has been appreciated and also criticized. One factor, that makes it appealing is that it provides a clear guideline which enhances the motivation of employees through the alteration of the individuals expectancies $(E \rightarrow P)$ instrumentalities $(\mathrm{P} \rightarrow \mathrm{O})$ and outcome valences (Mc shane and Glinow, 2000:77). Further, Aswathapa (2002:333) provided the following points. First, expectancy theory avail managers to see beyond the provisions in Maslow and Herzberg's theories that workers can only be motivated when work can satisfy unsatisfied needs.

Also, expectancy theory is a cognitive theory such that individuals are seen as thinking, reasoning beings who have beliefs and aspirations concerning future events in their lives "it is a model which values human dignity".

In spite of the above merits, the expectancy theory has been linked with several problems. First, as an important theory of motivation, it is yet to be empirically tested. It is complex and as a result is difficult to test in its entirety.

Second, the theory assumes that individuals make decisions consciously; there are however, instances where decisions are made without conscious thought. This is true particularly for routine jobs. It is proved that people could make decision with a conscious thought but later rationalize them, "rather that the use of the process indicated in the expectancy theory to make the decision in the first place".

\section{Equity Theory}

Equity theory is another process theory, and its origin emanated from the works of many prominent theories like Heider, Festinger, Homans, Patchen, Jacques and Adams. It is however, Adam's propositions of the equity theory which is the most highly developed and researched statement on the topic, Aswathapa (2000:334). Equity theory like other theories is known by other names, such as, "Social comparison theory" or "inequity theory". Equity theory is focused on the assumption that individuals are motivated by their desire to receive equitable treatment at work; This individual works in the anticipation of fair treatment. In this way, the individual worker does his or her work in exchange for rewards from the organization. The theory presents a specific process of how motivation occurs. Thus, "inequity exists for person whenever he perceives that the ratio of his outcomes (pay, status, promotion, or interest in the job) to inputs (efforts) and the ratio of other's outcomes to others' inputs are unequal" (Adams, 1975:141). 
Four important terms in equity theory are:

1) Person: The individual for whom equity or inequity is perceived.

2) Comparison other: Any group of or individual used by a person as reference regarding the ratio of inputs and outcomes.

3) Inputs: Characteristics which individuals brought with them to the job - (skills, education, experience) or ascribed (e.g., age sex, race).

4) Outcomes: What individual received from the job (e.g) recognition, pay fringe benefits).

Table: Other Examples of Inputs and Outcomes in Organisations

\begin{tabular}{|l|l|}
\hline Inputs & Outcomes \\
\hline Age & Challenging job assignments \\
\hline Attendance & Fringe benefits \\
\hline Interpersonal skills & Job requisites \\
\hline Communication skills & Job security \\
\hline Job effort (long hours) & Monotony \\
\hline Level of education & Promotion \\
\hline Past experience & Recognition \\
\hline Performance & Responsibility \\
\hline Personal appearance & Salary \\
\hline Seniority & Seniority benefits \\
\hline Social status & Status symbols \\
\hline Technical skills & Working conditions \\
\hline Training & \\
\hline
\end{tabular}

Source: Hellriegel, et al in Aswaltpapa (2002: 334)

IThe theory proposes that the motivation to act develops after the person compares inputs/outcomes with the identical ratio of the comparison other. Inequity is defined as the perception that person's job inputs/outcomes ratio is not equal to the inputs/outcomes ratio of the comparison other".

The equity proposal is of the assumption that the person upon feeling inequity, is motivated to reduce it. In addition, the greater the level of inequity felt, the greater the motivation to reduce it will be.

In the attempt to restoring equity, the person has the following number of alternatives:

1) Person changing his or her inputs

2) Person altering his or her outcomes.

3) Altering attitudes instead of person changing inputs or outcomes, he or she may alter attitudes by convincing oneself that the money paid is of less importance than other outcomes (e.g. Job security, convenient work place etc)

4) Person leaving the field - sequel to the perceived unfairness, you may decide to quit the job. 
5) Person trying to change or cognitively charge input and outcomes of the comparison others which compel him or her to leave the field.

6) Person altering the comparison other.

\section{Evaluation of the theory}

Equity theory like other theories has a number of advantages and limitations. As argued by Aswathapa (2002:336), the theory has generated extensive research, with many of the results that collaborates the theory. Secondly, it provides on insightful model to the explanation and prediction of employee attitudes concerning pay (Ivancivich, Konopaska, and Matteson, 2009:193).

However, Aswathapa (2002:336) stressed that the theme of the model is the judgment of equity treatment. The difficulty is that not all individuals have equal rate of appreciating fairness. Most of the research on the equity theory focused on pay as the basic outcomes, and thus failing to incorporate other relevant outcomes. This therefore limits the impacts of the theory in work places.

\section{Performance-Satisfaction Model}

Performance-satisfaction theory is a comprehensive theory of motivation that was developed by porter and Lawler. It is one of the integrative motivation models. This is because it combines both content and process theories of motivation. The crux of theory is that motivation, performances and satisfaction are all separate variables and that they relate in different ways from the traditional assumptions of their relatedness. It entails a multivariable relatedness. The multivariable model of porters and Lawler is shown in figure..... As mode explicit in the figure boxes 1.2 and 3 are basically similar to room's equation. Porter and Lawler stressed that an effort (force or motivation) does not directly result to a performance. It is influenced by proper skills abilities, traits and role perceptions. In essence the model stressed that the right person who has proper skills should be placed on the right job. More importantly, what prevails after the performance. For equitable distribution of rewards, performance should be effectively measured. Satisfaction is determined by the giving of fair distribution of rewards and how they are perceived. (Donnelly, Gibson and Ivancevich, 1984:327); Gray and Starke, 1988: 104).

\section{Evaluation of the Theory}

The foster and Lawler model is of great significance to managers because of its offer of the guidelines to motivate their employees. However, it has not had much influence on human resource management practice (Aswathapa, 2002:337). 


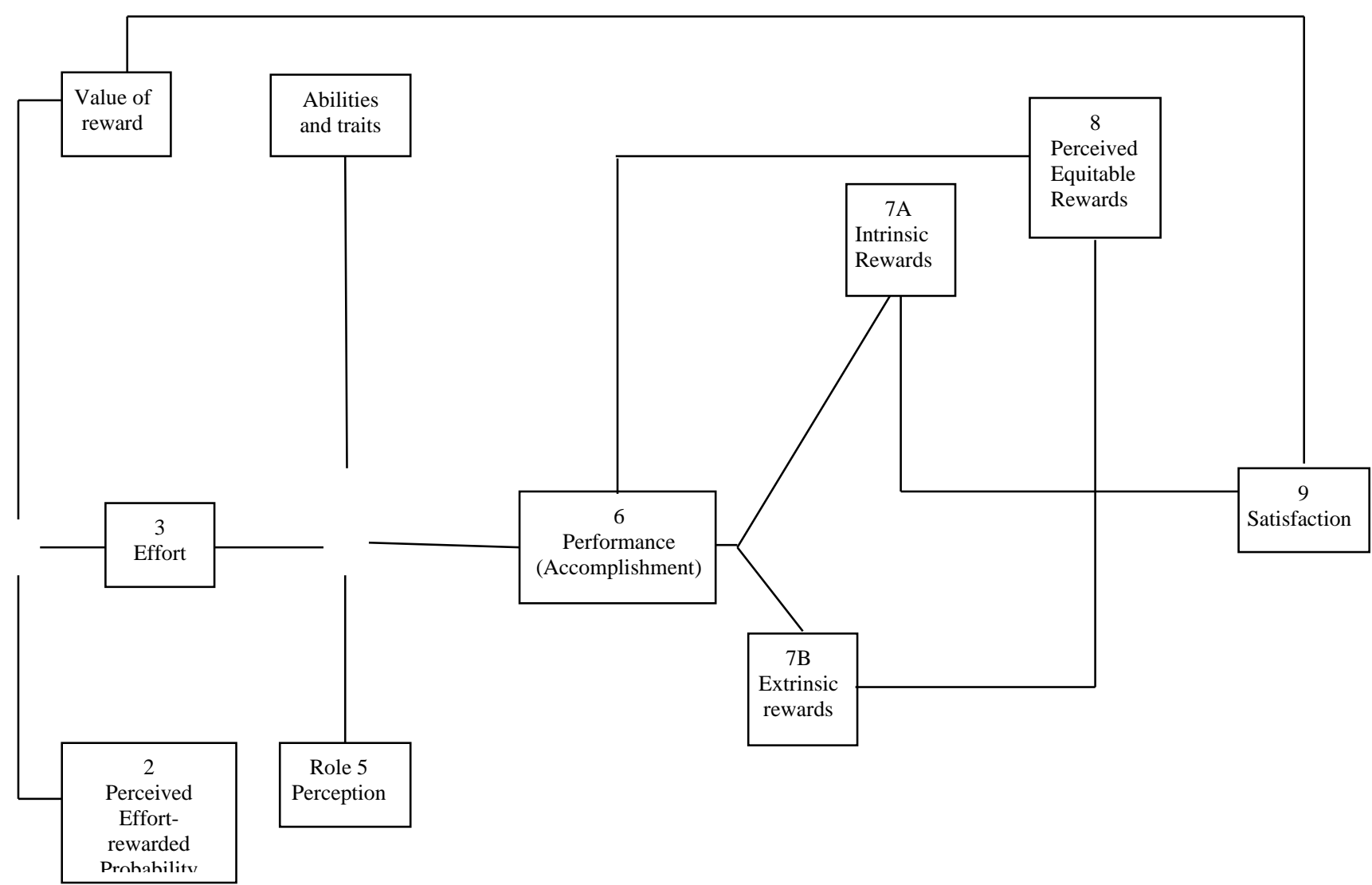

Fig 5:4: The porter and Lawler model of motivation source: Aswathapa, (2002:338).

\section{THEORY Z}

Theory $\mathrm{Z}$ is another theory of motivation with a distinctively Japanese approach to management. As an approach to motivation, its assumptions are geared towards the motivation of employees. The phase "theory Z" was carried by W. Ouchi, an American who the application of the Japanese practices.

Theory $\mathrm{Z}$ is another theory of motivation which has distinctive Japanese approaches to management. The phrase "theory Z" was carried by W. Ouchi, an American Ouchi (1981), who used it to explain attempts to apply the Japanese practice to the administrator of Western films. Over the period of three decades, Japanese manufacturing firms have recorded tremendous pace of process. This among other prominent factors, according to Ouchi is the distinctive approach to the management of the human resources, especially. Ouchi argues that Japanese industrial organisation's important features which includes the following personnel - related factors: 
(a) There exists a high level of initial trust and loyalty between management and employees.

(b) Decision-making is shared at virtually all levels.

(c) It involves a long-term performance appraisal; usually, the first appraisal is done after 10 years of employment with the organisation.

(d) Instead of the encouragement of individual achievement, prominence is giving to collective responsibility in order to enhance organizational success and corporative effort.

(e) Career paths are non-specialised with life-long job rotation being the central characteristics of career development.

As argued by Ouchi, a good number of the features of the Japanese management cannot be applied in the Western industrial society, he contends that some of the features if applied in Western firms, will be a success. It is quite clear that theory $\mathrm{Z}$, does not approve of the hierarchical system in organisations, rather, it is has the sole objective of developing the organizational ability to manage the human resource and not technology in order to achieve productivity. According to Ouchi, a new philosophy of managing the human resource is hinged on the combination of the following features:

(1) Life-long employment prospects;

(2) Relationships between boss and subordinate focused on reciprocity of respect.

(3) Shared pattern of decision making.

In the words of Cole (2004:48), these three steps requires the following approach;

- The adoption of a "top-down" approach, based on a definition of the "new" philosophy agreed and supported by the organisation's top management.

- The 'new' philosophy should embrace the ideas of security of employment, shared decision making, career development team spirit and acknowledgement of individual contribution within the team.

- The implementation of the new approach should be carried through on the basis of consultation and communication with the workforce and with full training support to develop relevant skills for managers, supervisors and their teams.

- It is pertinent to note as observed by Cole that the Japanese theory $\mathrm{Z}$ despite its participation management style has adopted most of the ideas of Frederick Taylor's scientific management.

- The present day Japan attaches much importance to engineering. "The acceptance of Taylorist approaches to manufacturing has enabled the Japanese to capture an enviable place in the world markets for their manufactured goods" (Cole, 2004:49). 


\section{Evaluation of Theory $Z$}

Theory $\mathrm{Z}$ has been acclaimed as the reason behind the success of most Japanese manufacturing firms. However, the theory is criticized of causing slow processes of decision making, lack of risk taking, and reliance on a plethora of small firms and part-time jobs. It has also being criticized of causing the imprisonment impact of lifetime employment in a particular company. Finally, it causes trade unions to be weak, (Ibid).

\section{REFERENCES}

Adams, S. (1975). Inequity in social change; in Steers Richard, M. and Lyman, W. P. Motivation and Work Behaviour. New York: McGraw-Hill Book Co.

Alderfer, C. P. (1972). Existence, Relatedness, and growth: human needs in organizational settings. New York: Free Press.

Armstrong, M. (2006). A handbook of human resource management practice $\left(10^{\text {th }} \mathrm{Ed}\right.$.). London: Kogan page Limited.

Aswathappa, K. (2002). Human resources and personnel management: Text and cases $\left(3^{\text {rd }}\right)$ (Edt.) New Delhi: Tata McGraw-Hill Publishing Company Ltd.

Cole, G. A. (2004). Management theory and practice. (6 ${ }^{\text {th }}$ edt). London: Thomson Learning.

Davis, K. and Newsfrom, J. W. (1989). Human behaviour at work. New York: McGraw-Hill.

Donnelly, J. H., Gibson, J. L. and Ivancevich, J. M. (1984). Fundamentals of management ( $5^{\text {th }}$ ed.). Texas: Business Publications Inc.

Feldman, D. C. and Arnold, H. J. (1983). Managing Individual and group behaviour in organisations. New York: McGraw-Hill.

Gabor, A. (2000). The capitalist philosophers. New York: Times Books.

Gray, J. L. and Starke, F. A. (1988). Organizational behaviour: Concepts and applications. Columbus: Merrill.

Harrel, T. W. (1972). Industrial psychology. New Delhi: Oxford and IBH Publishing Co.

Hellriegel, D. et al (2001). Organizational behaviour, South-Western.

Ivancevich, J. M., Konopaske, R. and Matteson, M. T. (2005). Organizational Behaviour and Management ( $7^{\text {th }}$ ed.). Nerw York: McGraw-Hill/Irwin.

Lawler, E. E. and Suttle, J. L. (1972). A causal correlation test of the need hierarchy concept, organizational behaviour and human performance.

Luthans, F. (1989). Organizational behaviour. New York: McGraw-Hill.

Mamoria, C. B. and Gankar, S. V. (2009). Personnel Management: Text and cases $\left(29^{\text {th }}\right.$ Edt). Mumbai: Himalaya Publishing house PVT Ltd.

Maslow, A. H. and Kaplan, A. R. (1998). Maslow on Management. New York: John Wiley.

McClelland, D. C. (1962). Business Drive and National Achievement. Harvard business review, pp. 99-112.

McShane, S. L. and Glinew, M. V. (2000). Organizational behaviour. Tata McGraw-Hill.

Ouchi, W. (1981). Theory Z. Wesley: Addison.

Peretomode, V. F. and Peretomode, O. (2001). Human resources management. Lagos: Obaroh and Ogbinika Publishers Ltd.

Salancik, G. R. and Pfeffer, J. (1977). An examination of need - satisfaction models of job attitudes. Administrative Science Quarterly, pp. 427-456.

Taylor, F. (1947). Scientific Management. New York: Harper and Row.

Thompson, P. and Mchugh, D. (2002). Work organisations. ( $3^{\text {rd }}$ ed.). New York: Palgrave.

Vroom, V. H. (1964). Work and motivation. New York: John Wiley and Sons. 